\title{
Production of Biodiesel from Yellow Oleander (Thevetia peruvian) Oil and its Biodegradability
}

\author{
Chindo Istifanus Yarkasuwa*, Danbature Wilson ${ }^{\dagger}$, and Emmanuel Michael ${ }^{\dagger}$ \\ Chemistry Programme, Abubakar Tafawa Balewa University, Bauchi, Nigeria \\ ${ }^{*}$ E-mail: istifanuschindo@yahoo.com \\ ${ }^{\dagger}$ Department of Chemistry, Gombe State University, Gombe, Nigeria.
}

(Received January 28, 2013; Accepted May 18, 2013)

\begin{abstract}
Thevetia peruviana (Yellow Oleander) seed oil was extracted with n-hexane in a soxhlet extractor. The ethanolysis and methanolysis of the oil were carried out with $50 \%$ of potassium hydroxide in ethanol and methanol respectively by weight of oil, as catalyst. The biodiesel was tested for biodegradability using E. coli. The percentage yield of the FAEE and FAME were $84.8 \%$ and $91.6 \%$ respectively. The biodegradability values of $81.4 \%$ and $86.2 \%$ were obtained for FAEE and FAME respectively after a period of 28 days. Other fuel quality parameters determined are the cetane index of 47.19 (FAEE) and 58.97 (FAME), flash point of $198^{\circ} \mathrm{C}$ (FAEE) and $175^{\circ} \mathrm{C}$ (FAME), kinematic viscosity at $40{ }^{\circ} \mathrm{C}$ of $5.21 \mathrm{~mm}^{2} \mathrm{~s}^{-1}$ (FAEE) and $5.10 \mathrm{~mm}^{2} \mathrm{~s}^{-1}$ (FAME), pour point of $4{ }^{\circ} \mathrm{C}\left(\right.$ FAEE) and $-2{ }^{\circ} \mathrm{C}\left(\right.$ FAME) and a cloud point of $6{ }^{\circ} \mathrm{C}(\mathrm{FAEE})$ and $3{ }^{\circ} \mathrm{C}(\mathrm{FAME})$. Thus, Thevetia peruviana oil has a high potential for use in production of environmentally friendly biodiesel.
\end{abstract}

Key words: Yellow Oleander, Biodiesel, Transesterification, Biodegradability

\section{INTRODUCTION}

Pioneering work in Europe and South Africa by researchers such as Martin Mittelbach furthered development of the biodiesel fuel industry in the early 1990s, with the U.S. industry coming on more slowly, due to lower prices for petroleum diesel. ${ }^{1}$ Pacific Biodiesel became one of the first biodiesel plants in the United States in 1996, establishing a biodiesel production operation to recycle used cooking oil into biodiesel on the island Maui in Hawaii. ${ }^{2}$ The biodiesel industry became a household name in the U.S. after the terrorist attacks of $9 / 11 / 2001$ resulted in historically high oil prices and an increased awareness of energy security. ${ }^{3,4}$ As of 2005 , worldwide biodiesel production had reached 1.1 billion gallons, with most fuel being produced in the European Union, although biodiesel projects worldwide have been on the rise due to rising crude oil prices and concerns over global warming. ${ }^{2}$

Due to its clean emissions profile, ease of use, and many other benefits, biodiesel is quickly becoming one of the fastest growing alternative fuels in the world. With minimal subsidy biodiesel is cost competitive with petroleum diesel, and millions of users have found and enjoyed the benefits of the fuel. ${ }^{5-7}$ The future of biodiesel lies in the world's ability to produce renewable feedstocks such as vegetable oils and fats to keep the cost of biodiesel competitive with petroleum, without supplanting land neces- sary for food production, or destroying natural ecosystems in the process. ${ }^{5,7}$ Creating biodiesel in a s ustainable manner, will allow this clean, renewable, and cost effective fuel to help ease the world through increasing shortages of petroleum, while providing economic and environmental benefits well into the 21 st century. ${ }^{1,2}$ In addition, a valuable by-product, glycerin (glycerol), may be used in the soap, pharmaceutical, and cosmetic industries. ${ }^{8}$

Owing to their availability, various oils have been in use in different countries as feedstocks for biodiesel production. Rapeseed and sunflower oils in Europe, soybean oil in U.S., palm oil in Malaysia and Indonesia and coconut oil in Philippines are being used for biodiesel production. Also, the seed oils of jatropha tree (Jatropha curcas), karanja (Pongamia pinnata) and mahua (M. indica) are used as major biodiesel fuel sources in India. ${ }^{9}$ In spite of this, biodiesel production from conventional vegetable oils (soybean, sunflower, safflower, palm, rapeseed etc.) has progressively stressed food uses, price, production and availability of these oils. ${ }^{10}$ Consequently, this has ignited the search for additional regional biodiesel raw materials. With 350 oil-bearing crops having been identified, recent studies on biodiesel from less common or unconventional oils include Moringa oleifera ${ }^{10}$ Michelia champaca and Garcinia indica, ${ }^{11}$ pumpkin, ${ }^{12}$ sea mango ${ }^{13}$ and desert date oils. ${ }^{14}$

The prices of fuel are going up day after day in the world. 
So, ways and means have been sought for many years to be able to produce oil-substitute fuel.

Biodiesel extracted from vegetable oil is one such renewable alternative under consideration. The production of biodiesel would be cheap as it could be extracted from non edible oil sources.

Thevetia peruviana, also known as Yellow Oleander, is a non-edible oil-bearing and drought-evergreen tropical shrub that belongs to the Apocynaceae family. ${ }^{15}$ The main objective of the present study was to investigate the suitability of the seed oil of "Yellow Oleander" as a feedstock for biodiesel production. The biodegradability of the biodiesels from this seed oil was also investigated.

\section{EXPERIMENTAL}

\section{Chemicals}

All commercial reagents and solvents were used without further purification unless otherwise specified. The oil used for the transesterification (production of the fatty acid methyl and ethyl esters) was obtained from the seeds of Thevetia peruviana (Yellow Oleander) by soxhlet extraction using $n$-hexane as solvent. The $n$-hexane, methanol, ethanol and other solvents used were obtained from Sigma Aldrich. The catalysts used KOH was from BDH Lab Supplies with $98 \%$ purity.

\section{Sampling and Sample Treatment}

Oil seed samples were hand - picked from the plant of Thevetia peruviana in a Botanical garden of Biological Science Department of Gombe State University. The sample seeds of Thevetia peruviana were cracked manually using a stone. The seeds were then ground using mortar and pestle to increase the surface area of the sample. The ground seed sample (100 g) was wrapped in a filter paper and put into a soxhlet extractor. The extraction was carried out at $70^{\circ} \mathrm{C}$ using normal hexane as the extracting solvent for $4 \mathrm{hrs}$. After exhaustive extraction the solvent was recovered using a rotary evaporator, leaving the oil behind. The above procedure was repeated several times until a reasonable quantity of the oil was obtained.

\section{Chemical Analysis of the Raw Thevetia peruviana Oils}

The free fatty acid (FFA), iodine value and the saponification value of the raw oil were determined based on ASTM D5555, ASTM D1959 and ASTM D464 respectively, while the peroxide value was determined based on European Pharmacopoeia 1/2005:20505. ${ }^{16}$
Preparation of Biodiesel from Thevetia peruviana Oils

Biodiesel was prepared with ethanol and methanol at the same reaction conditions. The transesterification was conducted using an alcohol to potassium hydroxide $(\mathrm{KOH})$ molar ratio of 5:1, at a temperature of $40^{\circ} \mathrm{C}$ and the reaction time of 20 minutes. Potassium hydroxide $(9.0 \mathrm{~g})$ was dissolved in $250 \mathrm{~cm}^{3}$ of ethanol and methanol to form potassium ethoxide and potassium methoxide respectively.

Yellow Oleander oil (20 g) was placed in a beaker and heated to the temperature of $40^{\circ} \mathrm{C}$, using a temperature controlled heating mantle with continuous stirring using a magnetic stirrer. The alcoholic/KOH solution (as catalyst) was then added to the warmed oil and stirred (vigorously at first and later slowly) for about 20 minutes until a homogenous mixture was formed. The mixture was then transferred into a separating funnel and allowed to stand overnight. After this period of time, the product separates into two layers. The lower layer contains a mixture of unreacted oil, potassium hydroxide, alcohol and glycerine, was drained off through the tap. The upper layer (biodiesel) was then washed with warm distilled water until the product was clear and neutral to litmus. The biodiesel was then heated at $100{ }^{\circ} \mathrm{C}$ to remove any water that might be present in the product. The end product, biodiesel was obtained as a clear amber-yellow liquid.

\section{Determination of Physical and Chemical Properties of Biodiesel}

The cetane index of biodiesel, flash point, pour point, cloud point, kinematic viscosity, specific gravity and the calorific value were determined by ASTM D.613, ASTM D.93, ASTM D.97, ASTM D.2500, ASTM D.445, ASTM D.1298 and ASTM D.2015 methods ${ }^{17}$ respectively.

\section{Procedure for Biodegradation of the Biodiesel}

The method employed for the biodegradability test was the respirometric method using $E$. colli bacteria. The innoculum was prepared by modifying the method reported by Andriano, et al. (2008). ${ }^{18}$

\section{Preparation of innoculum:}

To $500 \mathrm{ml}$ of de-ionized water, $0.5 \mathrm{~g}$ of organic matter rich soil, $1.0 \mathrm{ml}$ of aerated sewage mixed liquor, $25 \mathrm{ml}$ of raw domestic sewage water, $25 \mathrm{mg} / \mathrm{L}$ of yeast extract and E. coli bacteria were added respectively. ${ }^{18}$ The mixture was then allowed to stand for 14 days. At day 14, the inoculum was filtered and was ready for use.

\section{Procedure for biodegradation:}

The determinations of the ethyl and methyl esters biodegradability were carried out in a corked conical flask 
system. To the corked conical flask, $50 \mathrm{ml}$ inoculums, $450 \mathrm{ml}$ of de-ionized and distilled water; and $5.0 \mathrm{ml}$ of biodiesel were added and mixed throughly. The conical flask was connected via delivery tube to another well corked $50 \mathrm{ml}$ conical flask containing $10 \mathrm{ml}$ of calcium hydroxide solution to trap the evolved $\mathrm{CO}_{2}$. A similar but blank setup was used as a control. After inoculation, the flask were sealed and incubated with shaking in a dark cabinet. After every seven (7) days, the $10 \mathrm{ml}$ of $\mathrm{Ca}(\mathrm{OH})_{2}$ solution plus $30 \mathrm{ml}$ of rinsing water was removed for $\mathrm{CO}_{2}$ measurement by titrating with $0.1 \mathrm{M} \mathrm{HCl}$ with phenolphthalein as indicator. Each time the reservoir was refilled with fresh $\mathrm{Ca}(\mathrm{OH})_{2}$ solution. The $\mathrm{CO}_{2}$ was determined at time zero and four other times to allow biodegradation plot for the test sample. The same periodic determination of $\% \mathrm{CO}_{2}$ was carried out for the blank set up. The percentage $\mathrm{CO}_{2}$ evolved was obtained based on the following formula: ${ }^{18}$

$$
\% \mathrm{CO}_{2} \text { evolution }=\frac{T F-C F}{C} \times 100
$$

Where;

$\mathrm{TF}=$ volume of $0.1 \mathrm{M} \mathrm{HCl}$ required to titrate $\mathrm{Ca}(\mathrm{OH})_{2}$ sample from the test flask.

$\mathrm{CF}=$ volume of $0.1 \mathrm{M} \mathrm{HCl}$ required to titrate $\mathrm{Ca}(\mathrm{OH})_{2}$ from the control flask.

$\mathrm{C}=\mathrm{A}$ constant which is equal to the amount of $0.1 \mathrm{M}$ $\mathrm{HCl}$ required to titrate all the $\mathrm{CO}_{2}$ evolved from metabolizing total carbon in the test sample by bacteria, for example $10 \mathrm{mg}$ of carbon $=16.67$ of $0.1 \mathrm{M} \mathrm{HCl}$.

\section{RESULTS AND DISCUSSION}

The results of the free fatty acid content, moisture content, iodine value, saponification value, acid value and oil content of Thevetia peruviana are shown in Table 1.

In Table 1, it is observed that the seed contains about $2.0 \%$ of moisture. The moisture content of seed is a determining factor for the maximum length of time the seeds

Table 1. Analysis of chemical properties of Thevetia peruviana oil

\begin{tabular}{lc}
\hline Quality Parameter & Value \\
\hline Free fatty acid (\%) & 2.4 \\
Peroxide value (meq/kg) & 30.0 \\
Iodine value $(\%)$ & 12.6 \\
Saponification value (meq/kg) & 412.3 \\
Density at $30^{\circ} \mathrm{C}\left(\mathrm{gcm}^{-3}\right)$ & 0.921 \\
Acid value $(\%)$ & 4.7 \\
Viscosity at $40^{\circ} \mathrm{C}$ & 47 \\
Oil content of seed cake $(\%)$ & 67 \\
Moisture content of seed cake $(\%)$ & 2.2 \\
\hline
\end{tabular}

can be stored. ${ }^{19}$ The standard average moisture content of food varies between 8 and $22 \%{ }^{20}$ Seeds of high moisture content are subjected to rapid deterioration from mold growth, sprouting, heat and insect damage. ${ }^{19}$ This leads to the hydrolysis of the triglycerides to free fatty acids (FFA), which is costly to refine. ${ }^{21}$ A moisture content of $2 \%$ in Yellow Oleander suggests that the seed can be stored for a long period of time without affecting the oil quality.

The oil content of a seed determines whether the seed can be harnessed for commercial purpose, this very factor is the first to be considered among others when a large scale extraction of the oil is to be considered. And any seed with a percentage oil content which ranges from $40 \%$ and above is considered promising for commercial purpose. ${ }^{22}$ The oil content $(67 \%)$ of the seeds of Yellow Oleander obtained is considered promising and higher than that reported by Sahoo et al. $(62 \%)^{23}$ and exceeded the value for Jatropha curcas seed oil with 33-53.2\%. ${ }^{24}$

Since the production of biodiesel physically implies the reduction of the viscosity of the oil, therefore, for an oil to be considered good for the purpose of biodiesel production, it is required that it has a manageable viscosity. This will help to reduce the time it will take for the complete transesterification process. A drastic reduction in viscosity $\left(\right.$ at $\left.40^{\circ} \mathrm{C}\right)$ from the seed oil $\left(47 \mathrm{~mm}^{2} / \mathrm{s}\right)$ to the FAEE $\left(5.10 \mathrm{~mm}^{2} / \mathrm{s}\right)$ and FAME $\left(5.21 \mathrm{~mm}^{2} / \mathrm{s}\right)$ of Thevetia peruviana was observed.

A higher FFA value (2.4\%) of Yellow Oleander seed oil is observed compared to those reported by Sahoo et al. $(1.35 \%)^{22}$ and Oseni et al. $(1.96 \%),{ }^{26}$ perhaps due to geographical differences.

In Table 2, the percentage yield, which is the percentage of the oil that was trans-esterified to ethyl ester, was $84.8 \%$. This result shows that the oil of the seed of Thevetia peruviana can be harnessed for the commercial production of biodiesel. Both methanolysis and ethanolysis reaction of the seed oils of Thevetia peruviana gave biodiesel yields of 91.6 and 84.8 (\%) respectively, which are higher than that of the seed oil of Jatropha curcas ethyl ester, $69.52 \% .{ }^{24}$ Thus, seed oil of Thevetia peruviana is a promising feedstock for biodiesel production.

The cetane index also obtained as indicated in Table 2, is $47.19 \%$ for ethyl ester. The value was obtained by calculation using the formula:

$$
\text { Cetane index }=46.3+\left(\frac{5458}{S v}\right)-0.225 \times I v
$$

Where; $S v=$ Saponification value and $I v=$ Iodine value This value falls within the range stipulated for biodiesel 
Table 2. The quality parameters of Thevetia peruviana oil biodiesel in comparison with those of petro-diesel

\begin{tabular}{lcccc}
\hline Properties & $\begin{array}{c}\text { Biodiesel (Methyl Ester) from } \\
\text { Thevetia peruviana } \text { oil with } \\
\text { MeOH }\end{array}$ & $\begin{array}{c}\text { Biodiesel (Ethyl Ester) from } \\
\text { Thevetia peruviana } \text { oil with } \\
\text { EtOH }\end{array}$ & $\begin{array}{c}\text { ASTM D6751 } \\
\text { Standard for biodiesel } \\
\text { fuel }\end{array}$ & $\begin{array}{c}\text { ASTM D975 } \\
\text { Stard for diesel } \\
\text { fuel }\end{array}$ \\
\hline Density $\left(\mathrm{g} / \mathrm{m}^{3}\right)$ & 0.866 & 0.897 & 0.88 & 0.85 \\
Kinematic viscosity, $40^{\circ} \mathrm{C}\left(\mathrm{mm}^{2} / \mathrm{s}\right)$ & 5.10 & 5.21 & $1.9-6.0$ & $1.3-4.1$ \\
Saponification value $(\mathrm{meq} / \mathrm{kg})$ & 329.24 & 852.72 & - & - \\
Calorific value $(\mathrm{kJ} / \mathrm{gK})$ & 10920 & 8820 & - & 15120 \\
Iodine value $(\%)$ & 17.39 & 24.5 & - & - \\
Cetane index & 58.97 & 47.19 & $100-170$ & $40-55$ \\
Flash point $\left({ }^{\circ} \mathrm{C}\right)$ & 175 & 198 & & $60-80$ \\
Cloud point $\left({ }^{\circ} \mathrm{C}\right)$ & 3 & 6 & -15 to 10 & $(-35)-15$ \\
Pour point $\left({ }^{\circ} \mathrm{C}\right)$ & -2 & 4 & - & - \\
Percentage yield $(\%)$ & 91.6 & 84.8 & - & 26.82 \\
Biodegradability & 86.2 & 81.3 & -
\end{tabular}

by American standard (46-70). ${ }^{27}$ The value for the pour point and cloud point of the ethyl ester produced (Table 2), falls within the recommended range of -15 to $13^{\circ} \mathrm{C}$ and -14 to $16^{\circ} \mathrm{C}$ by the Department of Energy, USA. ${ }^{17,26}$

The flash point for FAEE $\left(198^{\circ} \mathrm{C}\right)$ obtained from the seed oil of Thevetia peruviana falls within the range $(>60.5$ or $37.8^{\circ} \mathrm{C}$ - depending upon the standard being applied) for combustible liquids ${ }^{16}$ and hence, its tendencies to cause any fire hazard are low.

The biodegradability obtained for FAEE and FAME after a period of four weeks is shown in Fig. 1. From the graph, it is found that the biodiesel from the seeds of Yellow Oleander is environmentally friendly, such that after spillage, it may only take about 28 days for about 81.3 and $86.2 \%$ of FAEE and FAME respectively to be totally degraded. It is not like petrodiesel which will take longer time to degrade to a maximum of $26.82 \%{ }^{15}$ Zhang et al. $(1998)^{25}$ explain that biodiesel is more easily metabolized than diesel because the former is a natural product consisting of pure fatty acids that are hydrocarbon chains with two oxy-

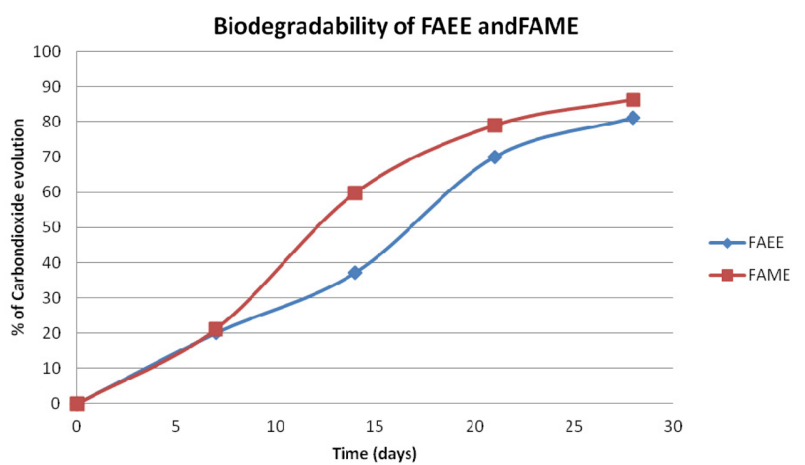

Figure 1. Biodegradability curve of FAEE and FAME after 28 days.
Table 3. Degradability of biodiesel from Thevetia peruviana oil after 28 days

\begin{tabular}{cccccc}
\hline \multirow{2}{*}{ S/No } & \multirow{2}{*}{ Days } & \multicolumn{2}{c}{ TF } & \multicolumn{2}{c}{$\% \mathrm{CO}_{2}$ Evolution } \\
\cline { 3 - 6 } & & FAEE & FAME & FAEE & FAME \\
\hline 1 & 0 & 0.0 & 0.0 & 0.00 & 0.00 \\
2 & 7 & 49.0 & 49.2 & 20.1 & 21.2 \\
3 & 14 & 51.8 & 55.6 & 37.2 & 59.8 \\
4 & 21 & 57.3 & 58.6 & 70.1 & 78.9 \\
5 & 28 & 59.15 & 60.0 & 81.3 & 86.2 \\
\hline
\end{tabular}

gen atoms attached at one end, which are very biologically active, being recognized and attacked immediately by enzymes such as acetyl-CoA dehydrogenase.

\section{CONCLUSION}

It is concluded that biodiesel quality parameters such as flash point ( 175 and $\left.198^{\circ} \mathrm{C}\right)$, saponification value (239.24 and $852.72 \mathrm{Meq} / \mathrm{kg}$ ), iodine value (17.39 and 24.5\%) and kinematic viscosity at $40{ }^{\circ} \mathrm{C}\left(5.10\right.$ and $\left.5.21 \mathrm{~mm}^{2} / \mathrm{s}\right)$ for the seed oil of Thevetia peruviana FAME and FAEE respectively are in strong agreement with those of ASTM standards. Also the fatty acid esters are biodegradable and thus the seed oil of Thevetia peruviana may be viable feedstock for good fuel which may cause only little effect to the environment in cases of spillage.

Acknowledgments. We wish to appreciate the Chemistry Department of Gombe State University for providing the working space for this research and also for furnishing us with all the reagents used for this research. And we also wish to appreciate the Biology Department of Gombe State University for providing the seeds of Thevetia peruviana 
(Yellow Oleander) for this research work. And the publication cost of this paper was supported by the Korean Chemical Society.

\section{REFERENCES}

1. Amigun, B.; von Blottnitz, H. Size Optimization of a Biodiesel Processing Plant: Environmental Process Engineering group, University of Cape Town: South Africa, 2005.

2. Pacific Biodiesel. http://www.biodiesel.com/index.php/biodiesel/history_of_biodiesel_fuel (accessed April 29, 2013).

3. Virgo, J. M. Atlantic Economic Journal 2001, 29, 4.

4. Weller, C. E.; Singleton, L. Economic Policy Institute. 2001, http://www.epi.org/content/fmm/issuebriefs_ib166.

5. Meher, L. C.; Sagar, D. V.; Naik, S. N. Renewable \& Sustainable Energy Reviews 2006, 10(3), 248-268.

6. Van Gerpen, J. Fuel Process. Technol. 2005, 86, 10971107.

7. Ramadhas, A. S.; Muraleedharan, C.; Jayaraj, S. Renewable Energy 2005, 30, 1789-1800.

8. Lewis, R. J. Sr. Hawley's condensed chemical dictionary, 12th ed.; Van Nostrand Reinhold Company: New York, 1993.

9. Demirbas, A. Renewable \& Sustainable Energy Reviews 2009, 50, 14-34.

10. Rashid, U.; Answar, F.; Moser, B. R. Bioresour. Technol. 2008, 99, 8175-8179.

11. Hosamani, K. M.; Hiremath, V. B.; Keri, R. S. Biomess \& Bioenergy 2009, 33, 267-270.

12. Schinas, P.; Karavalakis, G.; Davaris, C.; Anastopoulos, G.; Karonis, D.; Zannikos, F.; Stournas, S.; Lois, E. Biomass \& Bioenergy 2009, 33, 44-49.

13. Kansedo, J.; Lee, K. T.; Bhatia, S. Fuel 2009, 88, 11481150.
14. Chapagain, B. P.; Yehoshua, Y.; Wiesman, Z. Bioresour. Technol. 2009, 100, 1221-1226.

15. Missouri Botanical Garden. www.mobot.org/gardeninghelp (2011) (accessed January 20, 2012), Thevetia peruviana.

16. European Pharmacopoeia 1/2005:2050518.

17. Sahoo, N. K.; Naik, M. K.; Pradhan, S.; Naik, S. N.; Das, L. M. Journal of Biobased Materials and Bioenergy 2012, 6,3 .

18. Adriano, P. M.; Richard, C. T.; Luciano, M. O.; Jonas, C.; Dejanira, F. A. African Journal of Biotechnology 2008, 7(9), 1323.

19. TNAU Agritech Portal. 2008, www.agritech.tnau.ac.in/seed certification (accessed Feb 23, 2012).

20. Robertson, J. A.; Chapman, G. W.; Wilson, R. L. J. Am. Oil Chem. Soc. 1981, 4(61), 768.

21. Reece, D. L.; Peterson, L. C. A Report on the Idaho Road Vehicle Test with RME and Near Rapeseed Oil as an Alternative to Diesel Fuel. International summer meeting, Spokane, Washington, 1993; SAE paper 93, 5018.

22. Bioenergy Washington. http://www.bioenergy.wa.gov/oilseed.aspx (accessed May 21, 2012).

23. Sahoo, N. K.; Naik, M. K.; Pradhan, S.; Naik, S. N.; Das, L. M. Journal of Biobased Materials and Bioenergy 2012 , $6,3$.

24. Berchman, H. J.; Hirata, S. Bioresour. Technol. 2007, 99, 171.

25. Zhang, X.; Peterson, C. L.; Reece, D.; Haws, R.; Moller, G. Trans. ASAE. 1998, 41, 1423-1430.

26. Oseni, M. I.; Obetta, S. E.; Orukotan, F. V. American Journal of Scientific and Industrial Research 2012, 3(2), 62-68.

27. Biodiesel WWW Encyclopedia. www.bdpedia.com (2006): Accessed June 11, 2012. 